構造異性体を有するケミカルドラッグ成分の分析

土井佳代, ${ }^{*}, a$ 宮澤眞紀, ${ }^{a}$ 藤井 $\quad$ 寿, ${ }^{b}$ 小島 尚 ${ }^{a}$

\title{
The Analysis of the Chemical Drugs among Structural Isomer
}

\author{
Kayo DoI, ${ }^{*, a}$ Maki MiyazAwa, ${ }^{a}$ Hisashi FujII ${ }^{b}$ and Takashi KoJIMA ${ }^{a}$ \\ ${ }^{a}$ Kanagawa Prefectural Institute of Public Health, 1-3-1 Shimomachiya, Chigasaki City 253-0087, Japan and \\ ${ }^{b}$ Kanagawa Industrial Technology Center, 705-1 Shimoimaizumi, Ebina City 243-0435, Japan
}

(Received March 3, 2006; Accepted June 20, 2006; Published online June 22, 2006)

\begin{abstract}
Drugs that have a pharmacological effect similar to legal drugs such as narcotics and stimulants are available in the market and widely used. 5-methoxy- $N, N$-di-iso-propyl-tryptamine (5MeO-DIPT) and $\alpha$-methyl-tryptamine (AMT) were categorized as narcotics and were specified as legal drugs in April 2005, and also 2,5-dimethoxy-4- $n$-propylthiophenethylamine (4C-T-7) and $N$-methyl- $\alpha$-ethy-3,4-methylenedioxy-phenethylamine (MBDB) were categorized as narcotics and were specified as legal drugs in April 2006, in Japan. We are analyzing these chemical drugs by investigating the market research. It is recognized that during the analysis of chemical drugs, drugs that resemble a structural isomer of a target substance, such as 5MeO-DIPT and 5-methoxy- $N, N$-di- $n$-propyl-tryptamine (5MeO-DPT) or $4 \mathrm{C}$-T-7 and 2,5-dimethoxy-4-iso-propylthiophenethylamine (4C-T-4), should be distinguished. The results of TLC, IR, GC-MS and HPLC analyses were compared. 5MeO-DIPT and 5MeO-DPT could be distinguished by TLC and HPLC analyses, but not by IR and GC-MS analysis. The drugs 4-hydroxy- $N$-methyl- $N$-iso-propyl-tryptamine (4HO-MIPT) and 4-hydroxy$N, N$-di-ethyl-tryptamine (4HO-DET) or could not be distinguished. Moreover, the isomers of 4-hydroxy- $N$-methyl- $N$ $n$-propyl-tryptamine (4HO-MPT) was not found to be present. Thus, we have demonstrated that the chemical drug could be distinguished from each other, and we have also shown that NMR data is essential for the analysis.
\end{abstract}

Key words - abuse drug; structural isomerism; 5-methoxy- $N, N$-di-iso-propyl-tryptamine; 5-methoxy- $N, N$-di- $n$ propyl-tryptamine; chemical drug

\section{緒言}

麻薬や覚せい剤などによる犯罪事件はあとを絶た ないが，近年それらのゲートウエィドラッグとし て，多幸感や快感等を高めることを目的に未規制薬 物が使用されることによる問題件数が増加してお

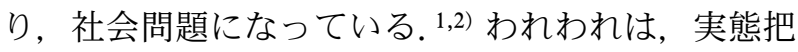
握のために未規制薬物の試買調査を実施し，成分の 確認を行っている. ${ }^{3,4)}$ 平成 17 年 4 月 17 日にケミカ ルドラッグとして広く使われていた 5-methoxy$N, N$-di-iso-propyl-tryptamine (5MeO-DIPT) と $\alpha$ methyl-tryptamine (AMT) が，また平成 18 年 4 月 22 日に 2,5-dimethoxy-4- $n$-propylthiophenethylamine （2C-T-7）及び $N$-methyl- $\alpha$-ethy-3,4-methylenedioxyphenethylamine (MBDB) が麻薬に指定された。違 法な薬物であるか否かは，その物質の化学構造式に

$a$ 神奈川県衛生研究所, $b$ 神奈川県産業技術センター

*e-mail: doi.1d8x@pref.kanagawa.jp
よって定められている. 薬物の分子構造の一部を別 のものに置き換えた「デザイナー・ドラッグズ」と して知られる一種の類似薬物もケミカルドラッグと して流通している，麻薬に指定された 5MeO-DIPT 及び 2C-T-7 の連鎖構造異性体である5-methoxy$N, N$-di-n-propyl-tryptamine (5MeO-DPT) 及び 2,5dimethoxy-4-iso-propylthiophenethylamine (2C-T-4) も実際に販売されており, またピペラジン系の1(2-chlorophenyl)-piperazine (2CPP), 1-(3-chlorophenyl)-piperazine (3CPP) 及び 1-(4-chlorophenyl) piperazine (4CPP) はそれぞれ互いに位置異性体で ありこれらも販売されている．構造異性体の生体影 響の違いは多くの成分で明らかになっていないこと から，また法律の規制上からこれらの成分の確認に は構造異性体の区別が求められる。しかし，これら のケミカルドラッグの分析に多用されるマスフラグ メントや IR スペクトルでは違いを証明することは 難しい。そこで，これらの成分に関する GC-MS, 
HPLC, IR や TLC による分析を行い，異性体の判 別に関する検討を行ったので報告する.

\section{実 験 の 部}

1. 試薬 Table 1 に使用したケミカルドラッ グの名称等を，Fig. 1 にその構造式を示した。ま た，その由来は，5MeO-DPT は Nantong Chang Chemical 製を，AMT 及び $N \omega$-methyl-tryptamine (NMT) は Aldrich 製を, 5-methyl-tryptamine (5MT) は Aldrich 製の塩酸塩を，ピペラジン系の 2CPP 及 び 1- (2-methoxyphenyl)-piperazine (2MPP) は東京 化成製を，4CPP 及び 3CPP は東京化成製の塩酸 塩を, 1-(4-methoxyphenyl)-piperazine (4MPP) は Aldrich 製の二塩酸塩を，5MeO-DIPT， N,N-di-isopropyl-tryptamine (DIPT), $N, N$-di- $n$-propyl-tryptamine (DPT), 4-hydroxy- $N$-methyl- $N$-iso-propyl-tryptamine (4HO-MIPT) 及び 4-hydroxy- $N, N$-di-ethyltryptamine (4HO-DET), フェネチルアミン系の 2,4,5-tri-methoxy-amphetamine (TMA-2), 2,4,6-trimethoxy-amphetamine (TMA-6)，2C-T-7 及び 2CT-4 は入手し得た由来不明の試薬について MS 及び NMR により成分の同定を行い，HPLC により純度 を確認したものを用いた（Table 2)。メタノール等
溶解に用いた試薬はすべて和光純薬製特級を用いた.

2. GC-MS の測定 GC-MS 装置は GC 部 Agilent 6890N（アジレントテクノロジー）の日本 電子製の JMS GC-mate II を用いた。 GC 条件はカ ラムにアジレントテクノロジー製の HP-5（内径 $0.32 \mathrm{~mm}$, 長さ $30 \mathrm{~m}$, 膜厚 $0.25 \mathrm{~mm}$ ）を用い, 注 入口温度 : $200^{\circ} \mathrm{C}$, カラム温度 : $100^{\circ} \mathrm{C}$ から $250^{\circ} \mathrm{C}$ に 1 分間 $10^{\circ} \mathrm{C}$ 昇温, インレット温度 : $250^{\circ} \mathrm{C}$ で行 つた. MS 条件は，イオン化方法：電子イオン法 (EI)，加速電圧 : $2500 \mathrm{~V}$ ，フィラメント電流：300 $\mathrm{mA}$, 分解能 : 500 で行った。 また, 同一の MS 条 件により直接導入法による測定も行った.

3. TLCによる測定薄層板は Merck 製の HPTLC silicagel $60 \mathrm{~F}_{254}$ を用い，展開溶媒には chloroform/methanol $/ 28 \%$ ammonia $(90: 10: 0.5)$ を 用いて展開し，検出は紫外線照射（波長 $254 \mathrm{~nm}$ ), ニンヒドリン試液あるいはドラーゲンドルフ試液噴 霧による呈色を観察した。TLCによる検出は,

TMA-2 及び TMA-6 がニンヒドリン試液では呈色 しなかった以外はすべて検出し，TMA-6 以外は紫 外線照射で $0.4 \mu \mathrm{g}$ のスポットで確認された。

TMA-6 はドラーゲンドルフ試液により $1 \mu \mathrm{g}$ が検出 限度であった。

Table 1. Chemical Drugs for Sample

\begin{tabular}{|c|c|c|c|c|}
\hline Type & Name & Chemical drug & Rational formula & Mol. weight \\
\hline \multirow{9}{*}{ Tryptamine } & $5 \mathrm{MeO}-\mathrm{DIPT}$ & 5-methoxy- $N, N$-di-iso-propyl-tryptamine & $\mathrm{C}_{17} \mathrm{H}_{26} \mathrm{~N}_{2} \mathrm{O}$ & 274.20 \\
\hline & $5 \mathrm{MeO}-\mathrm{DPT}$ & 5-methoxy- $N, N$-di- $n$-propyl-tryptamine & $\mathrm{C}_{17} \mathrm{H}_{26} \mathrm{~N}_{2} \mathrm{O}$ & 274.20 \\
\hline & DIPT & $N, N$-di-iso-propyl-tryptamine & $\mathrm{C}_{16} \mathrm{H}_{24} \mathrm{~N}_{2}$ & 244.38 \\
\hline & DPT & $N, N$-di- $n$-propyl-tryptamine & $\mathrm{C}_{16} \mathrm{H}_{24} \mathrm{~N}_{2}$ & 244.38 \\
\hline & AMT & $\alpha$-methyl-tryptamine & $\mathrm{C}_{11} \mathrm{H}_{14} \mathrm{~N}_{2}$ & 174.24 \\
\hline & NMT & $N \omega$-Methyltryptamine & $\mathrm{C}_{11} \mathrm{H}_{14} \mathrm{~N}_{2}$ & 174.24 \\
\hline & $5 \mathrm{MT}$ & 5-Methyl-tryptamine & $\mathrm{C}_{11} \mathrm{H}_{14} \mathrm{~N}_{2}$ & 174.24 \\
\hline & 4HO-MIPT & 4-hydroxy- $N$-methyl- $N$-iso-propyl-tryptamine & $\mathrm{C}_{14} \mathrm{H}_{20} \mathrm{~N}_{2} \mathrm{O}$ & 232.32 \\
\hline & 4HO-DET & 4-hydroxy- $N, N$-di-ethyl-tryptamine & $\mathrm{C}_{14} \mathrm{H}_{20} \mathrm{~N}_{2} \mathrm{O}$ & 232.32 \\
\hline \multirow{5}{*}{ Piperazine } & $2 \mathrm{CPP}$ & 1-(2-chlorophenyl)-piperazine & $\mathrm{C}_{10} \mathrm{H}_{13} \mathrm{ClN}_{2}$ & 196.68 \\
\hline & $3 \mathrm{CPP}$ & 1-(3-chlorophenyl)-piperazine & $\mathrm{C}_{10} \mathrm{H}_{13} \mathrm{ClN}_{2}$ & 196.68 \\
\hline & $4 \mathrm{CPP}$ & 1-(4-chlorophenyl)-piperazine & $\mathrm{C}_{10} \mathrm{H}_{13} \mathrm{ClN}_{2}$ & 196.68 \\
\hline & 2MPP & 1-(2-methoxyphenyl)-piperazine & $\mathrm{C}_{11} \mathrm{H}_{16} \mathrm{~N}_{2} \mathrm{O}$ & 192.26 \\
\hline & 4MPP & 1-(4-methoxyphenyl)-piperazine & $\mathrm{C}_{11} \mathrm{H}_{16} \mathrm{~N}_{2} \mathrm{O}$ & 192.26 \\
\hline \multirow{4}{*}{ Phenethylamine } & TMA-2 & 2,4,5-tri-methoxy-amphetamine & $\mathrm{C}_{12} \mathrm{H}_{19} \mathrm{NO}_{3}$ & 225.28 \\
\hline & TMA-6 & 2,4,6-tri-methoxy-amphetamine & $\mathrm{C}_{12} \mathrm{H}_{19} \mathrm{NO}_{3}$ & 225.28 \\
\hline & $2 \mathrm{C}-\mathrm{T}-4$ & 2,5-di-methoxy-4-iso-propylthiophenethylamine & $\mathrm{C}_{13} \mathrm{H}_{21} \mathrm{NO}_{2} \mathrm{~S}$ & 255.38 \\
\hline & $2 \mathrm{C}-\mathrm{T}-7$ & 2,5-di-methoxy-4-n-propylthiophenethylamine & $\mathrm{C}_{13} \mathrm{H}_{21} \mathrm{NO}_{2} \mathrm{~S}$ & 255.38 \\
\hline
\end{tabular}


Tryptamine type<smiles>[R]c1ccc2[nH]cc(CC([R9])N([R6])[R6])c2c1[R]</smiles>

\begin{tabular}{lccccc}
\hline \hline \multicolumn{1}{c}{ Drug } & $\mathrm{R}_{1}$ & $\mathrm{R}_{2}$ & $\mathrm{R}_{3}$ & $\mathrm{R}_{4}$ & $\mathrm{R}_{5}$ \\
\hline 5MeO-DIPT & $\mathrm{H}$ & $\mathrm{MeO}$ & iso-propyl & iso-propyl & $\mathrm{H}$ \\
5MeO-DPT & $\mathrm{H}$ & $\mathrm{MeO}$ & $n$-propyl & $n$-propyl & $\mathrm{H}$ \\
DIPT & $\mathrm{H}$ & $\mathrm{H}$ & iso-propyl & iso-propyl & $\mathrm{H}$ \\
DPT & $\mathrm{H}$ & $\mathrm{H}$ & $n$-propyl & $n$-propyl & $\mathrm{H}$ \\
AMT & $\mathrm{H}$ & $\mathrm{H}$ & $\mathrm{H}$ & $\mathrm{H}$ & $\mathrm{CH}_{3}$ \\
NMT & $\mathrm{H}$ & $\mathrm{H}$ & $\mathrm{H}$ & $\mathrm{CH}_{3}$ & $\mathrm{H}$ \\
5MT & $\mathrm{H}$ & $\mathrm{CH}_{3}$ & $\mathrm{H}$ & $\mathrm{H}$ & $\mathrm{H}$ \\
4HO-MIPT & $\mathrm{OH}$ & $\mathrm{H}$ & $\mathrm{CH}_{3}$ & iso-propyl & $\mathrm{H}$ \\
4HO-DET & $\mathrm{OH}$ & $\mathrm{H}$ & $\mathrm{C}_{2} \mathrm{H}_{5}$ & $\mathrm{C}_{2} \mathrm{H}_{5}$ & $\mathrm{H}$ \\
\hline
\end{tabular}

Piperazine type

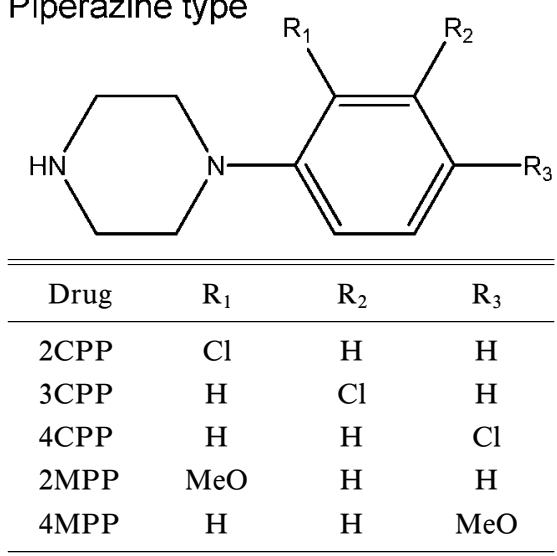

Phenetylamine type

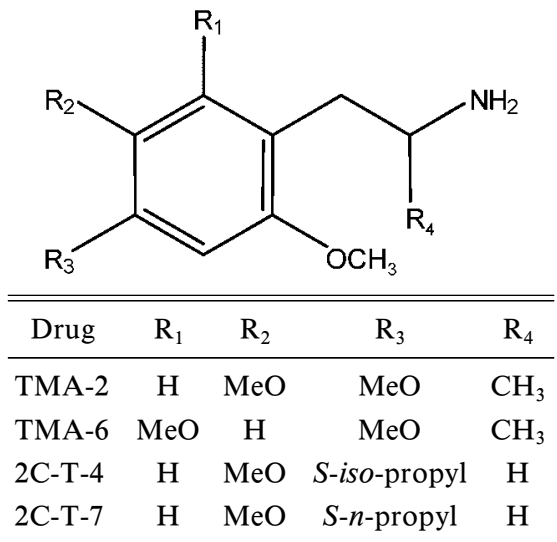

Fig. 1. Structures of Chemical Drugs for Sample

4. HPLC による測定ＨPLC 装置は Waters 製の蛍光分光検出器 $(E x: 285 \mathrm{~nm}, \mathrm{Em}: 450 \mathrm{~nm}$ ) 及 びフォトダイオドアレイ検出器（210-400 nm，検 出波長：280 nm）を装着した Alliance2690system により, カラムは, Inertsil ODS-3（粒径 $3 \mu \mathrm{m}, 4.0$ $\mathrm{mm} \phi \times 100 \mathrm{~mm}$ ，ジーエルサイエンス製），カラム 温度は $40^{\circ} \mathrm{C}$ ，移動相は $\mathrm{A}$ 液（0.01 mol $/ 1$ 酶酸ナト リウム緩衝液（pH 4.25））及び B 液（アセトニト リル）を用い， $1.0 \mathrm{ml} / \mathrm{min}$. で A 液を 10 分間で 95 \%から $80 \%$ に，次の 10 分間で $80 \%$ から $70 \%$ に混 合して送液した。トリプタミン系は蛍光分光検出器 により測定できたが，ピペラジン系あるいはフェネ チルアミン系では検出しなかった。

5. IR による測定 IR 装置は，パーキンエル マー製の FT-IR スペクトロメトリーを用い, 分解 能 $4.00 \mathrm{~cm}^{-1}$ ， スキャン速度 $0.20 \mathrm{~cm} / \mathrm{s}$ により，臭 化カリウム錠剤を作成して測定した。

6. FT-NMRによる測定 FT-NMR 装置は日
本電子製の JNM-A400 を用い，測定核種は ${ }^{1} \mathrm{H}$ ，共 鳴周波数は $399.65 \mathrm{MHz}$ ，積算回数は 128 回，測定 温度は $25 \pm 0.2^{\circ} \mathrm{C}$ で測定し，溶媒は重水あるいは重 クロロホルムを用いた.

\section{実 験 結 果}

\section{DIPT とDPT 等連鎖構造異性体 Table 3} に各試料成分について GC-MS 及び HPLC を測定 して得られた保持時間等を示した. Figure 1 に示し た構造を有する $5 \mathrm{MeO}-\mathrm{DIPT} と 5 \mathrm{MeO}-\mathrm{DPT}$ は, GC-MS による測定では，Fig. 2 に示すように保持 時間は 14.3 分及び 14.5 分と接近しており，また MS スペクトルは，分子イオンは $m / z 274$ に認めた が，イオンの相対強度は弱かった。その他 174 , 160, 145, 114 等にフラグメントイオンを認め, 両者 に違いは得られず，区別することは不可能であっ た。 そこで，Fig. 3 に示すように HPLC による測 定を行った結果， 13.3 分と 15.3 分と保持時間に差 


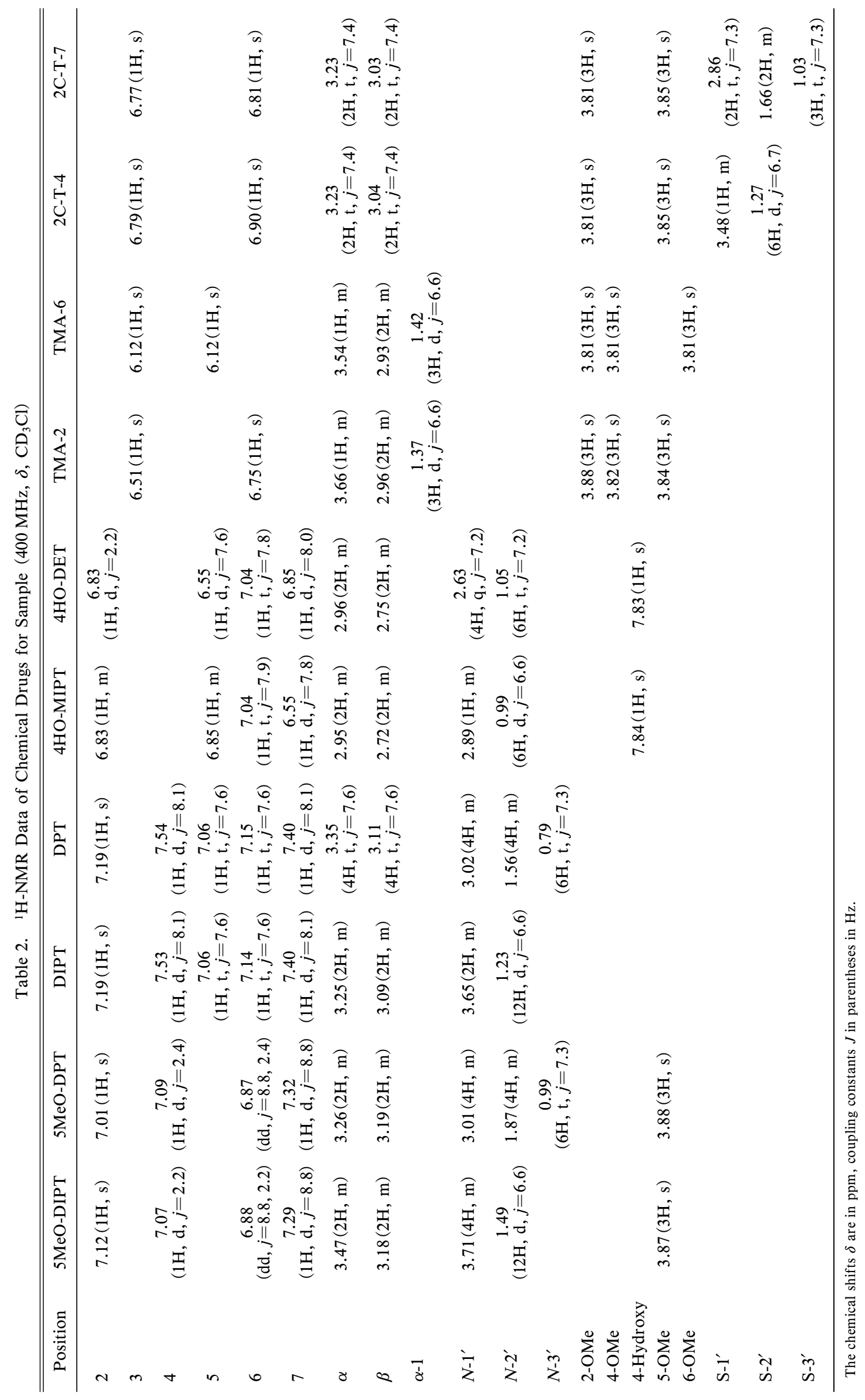


Table 3. Data of GC/MS, HPLC/PDA and TLC of Chemical Drugs

\begin{tabular}{|c|c|c|c|c|}
\hline $\begin{array}{c}\text { Chemical } \\
\text { drug }\end{array}$ & $\stackrel{\mathrm{GC}}{\text { r.t. }(\min )}$ & $\begin{array}{c}\text { EI-MS } \\
m / z\end{array}$ & $\begin{array}{l}\text { HPLC } \\
\text { r.t. (min) }\end{array}$ & $\begin{array}{c}\text { TLC } \\
\text { Rf value }\end{array}$ \\
\hline $5 \mathrm{MeO}-\mathrm{DIPT}$ & 14.3 & $(274), 174,160,145,114^{*}, 86,72$ & 13.3 & 0.32 \\
\hline $5 \mathrm{MeO}-\mathrm{DPT}$ & 14.5 & $(274), 174,160,145,114^{*}, 86,72$ & 15.5 & 0.47 \\
\hline DIPT & 12.4 & $144,130,114^{*}, 72$ & 13.6 & 0.32 \\
\hline DPT & 12.6 & $144,130,114^{*}, 72$ & 15.9 & 0.47 \\
\hline AMT & 9.3 & $(174), 131^{*}, 103,77$ & 7.2 & 0.12 \\
\hline NMT & 9.7 & $(174), 131^{*}, 103,77$ & 7.2 & 0.08 \\
\hline $5 \mathrm{MT}$ & 10.1 & $174,144^{*}, 115$ & 9.7 & 0.09 \\
\hline 4HO-MIPT & 13.4 & $232,(160),(146), 86^{*}$ & 7.2 & 0.37 \\
\hline 4HO-DET & 13.3 & $232,(160),(146), 86^{*}$ & 7.1 & 0.37 \\
\hline $2 \mathrm{CPP}$ & 7.8 & $196,154^{*}, 139,111,77,75$ & 10.5 & 0.29 \\
\hline $3 \mathrm{CPP}$ & 9.1 & $196,154^{*}, 139,111,77,75$ & 11.5 & 0.33 \\
\hline $4 \mathrm{CPP}$ & 9.2 & $196,154^{*}, 139,111,77,75$ & 11.4 & 0.29 \\
\hline 2MPP & 8.0 & $192,150^{*}, 135,120$ & 10.2 & 0.27 \\
\hline $4 \mathrm{MPP}$ & 9.3 & $192,150^{*}, 135,120$ & 6.5 & 0.25 \\
\hline TMA-2 & 9.1 & $(225), 182^{*}, 167,151$ & 8.2 & 0.31 \\
\hline TMA-6 & 9.4 & $182^{*}, 167,151,136,121$ & 12.0 & 0.23 \\
\hline $2 \mathrm{C}-\mathrm{T}-4$ & 11.3 & $255,226^{*}, 183,169,153$ & 17.0 & 0.27 \\
\hline $2 \mathrm{C}-\mathrm{T}-7$ & 12.0 & $255,226,183^{*}, 169,153$ & 18.1 & 0.27 \\
\hline
\end{tabular}

Values in parentheses represent the less than $8 \%$ of relative intensity. *: $100 \%$ of relative intensity.

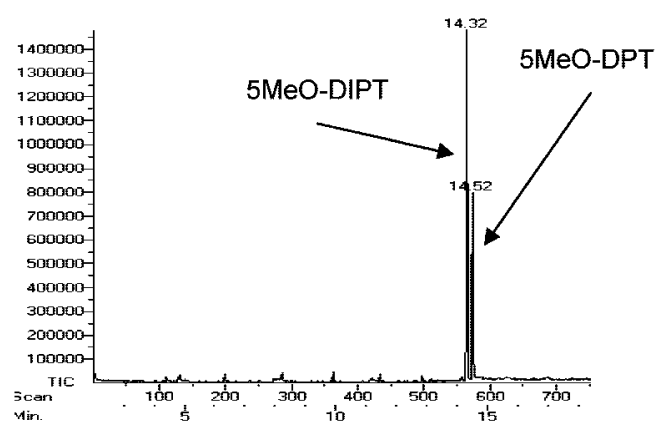

Scan

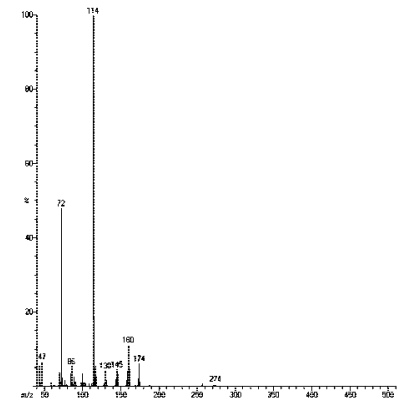

5MeO-DIPT

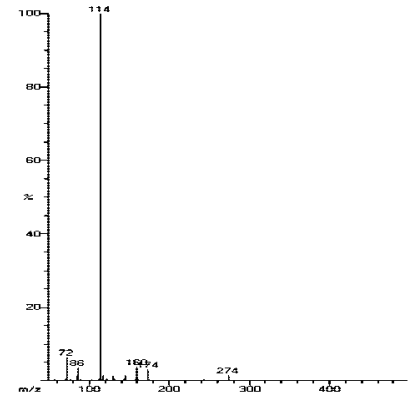

$5 \mathrm{MeO}-\mathrm{DPT}$

Fig. 2. GC Chromatogram and Mass Spectra of 5MeO-DIPT and 5MeO-DPT

を認め，区別することができた．また，簡易な測定 方法として TLC について検討した結果，区別する ことができた。同様に DIPT 及び DPT でも GC の 保持時間は 12.4 分と 12.6 分と接近し, MS スペク トルもほとんど相似しており，区別が付かなかった が，HPLC 及び TLC では保持時間あるいは Rf 值 が異なることから区別することが可能であった。 む しろ HPLCでは, Fig. 3 に示したように, 5MeODIPT の保持時間が 13.3 分に対し DIPT が 13.6 分, 5-MeO-DPT の保持時間が 15.3 分に対し DPT は 15.9 分と, インドール骨格の 5 位に配位した methoxyl 基の影響が弱かつた．また，IR スペクト ルを比較した結果, Table 4 に示したように $5 \mathrm{MeO}-$ DIPT と 5MeO-DPT は主要なスペクトルは同一波 数付近に同様の吸収を認め, また, DIPT と DPT も同一波数付近に同様の吸収を認めた.

4HO-MIPT と 4HO-DET は, GC と HPLC の保 持時間では区別できず，また MS スペクトルも同 じだった。また，IR スペクトルを比較した結果， 主要なスペクトルは同一波数付近に同様の吸収を認 めた. TLCの Rf 值は 0.37 と接近していた.

フェネチルアミン系の $2 \mathrm{C}-\mathrm{T}-7$ と 2C-T-4 は, $\mathrm{GC}$ 


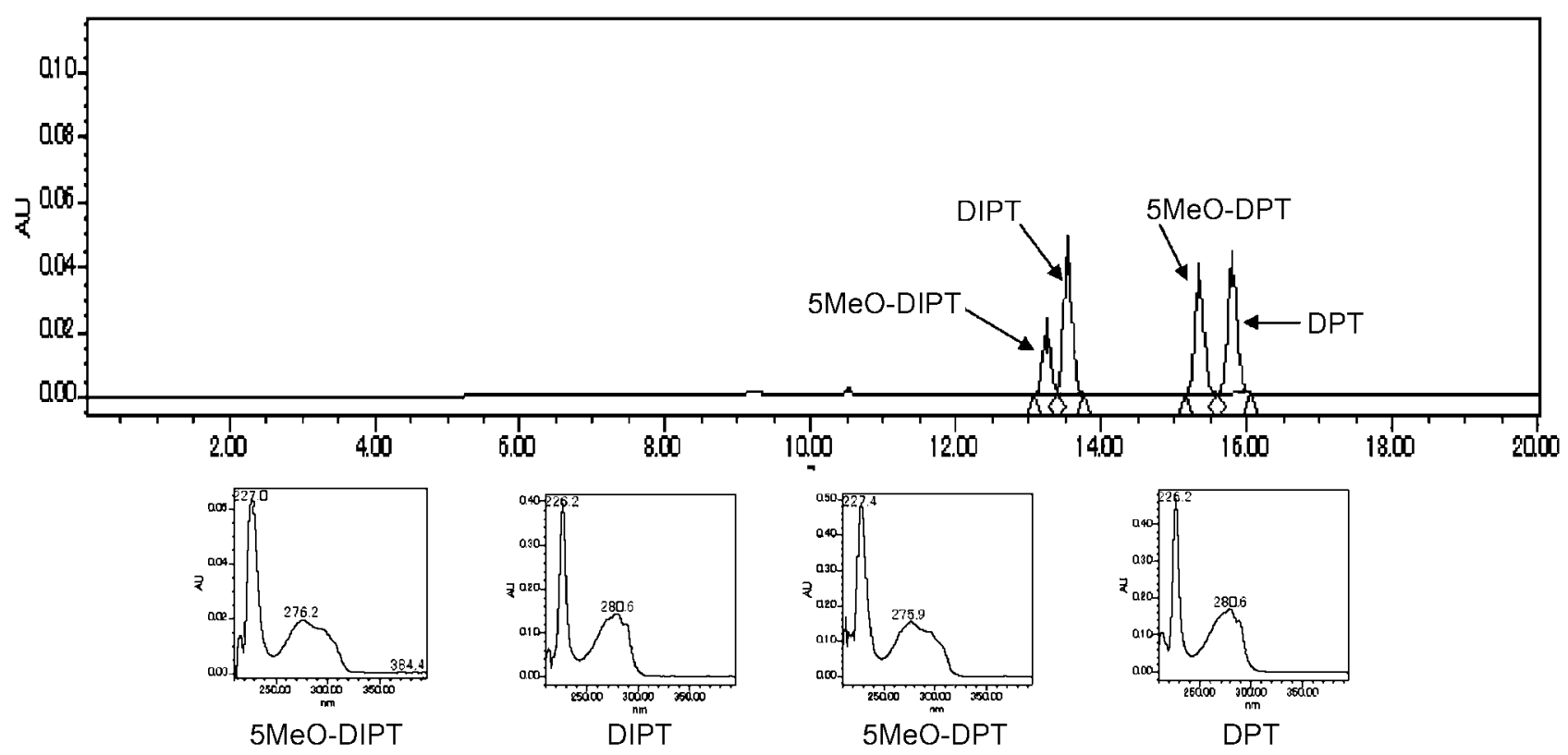

Fig. 3. HPLC Chromatogram and UV Spectra of 5MeO-DIPT, 5MeO-DPT, DIPT and DPT

Table 4. IR Spectrum Data of Chemical Drugs

\begin{tabular}{ll}
\hline \hline Chemical drug & \multicolumn{1}{c}{ Main wavenumber of IR spectrum $\left(\mathrm{cm}^{-1}\right)$} \\
\hline 5MeO-DIPT & $3205,2926,2664,1626,1590,1492,1440,1256,1071,822,643$ \\
5 MeO-DPT & $3235,2936,2651,1623,1586,1490,1437,1224,1074,808,639$ \\
\hline DIPT & $3182,2926,2660,1430,1394,1340,1237,1127,1092,746$ \\
DPT & $3212,2944,2637,1458,1381,1341,1248,1098,1098,754$ \\
\hline AMT & $3359,1619,1579,1454,1358,1232,1107,1088,1010,966,927,905,810,737$ \\
NMT & $3299,1622,1454,1341,1102,1013,901,798,739$ \\
5 MT & $3274,1607,1514,1435,1233,1101,801,627,555$ \\
\hline 4 HO-MIPT & $3248,2975,1582,1504,1354,1264,1040,733$ \\
4 HO-DET & $3235,2989,1576,1500,1359,1266,1056,741$ \\
\hline 2CPP & $2816,1553,1481,1288,1126,1036,928,763,686$ \\
3CPP & $2929,2775,1596,1490,1257,1156,945,751,676$ \\
4 CPP & $3436,2916,2709,2494,1595,1497,1455,1255,1149,918,819,557$ \\
\hline 2MPP & $3431,2946,2823,1594,1501,1448,1243,1026,754$ \\
4 MPP & $3436,2959,2509,1604,1518,1445,1255,1018,836,594,544$ \\
\hline TMA-2 & $3197,2875,1593,1525,1227,1205,1037$ \\
TMA-6 & $3435,2931,1922,1616,1156,837,696$ \\
\hline 2C-T-4 & $3436,2961,1600,1493,1465,1383,1211,1039,861,807$ \\
2 C-T-7 & $3436,2963,1604,1495,1464,1396,1209,1040,852,813$ \\
\hline
\end{tabular}

と HPLC の保持時間で区別できたが，TLCでは区 別できなかった。 また，MS スペクトルは検出した フラグメントイオンは同じだったがイオン相対強度 が異なり，IR スペクトルを比較した結果，主要な スペクトルは同一波数付近に同様の吸収を認めた.
2. AMT, 2CPP 及び TMA-2 等の位置構造異性 体 AMT, NMT 及び 5MT は, Tryptamine に methyl 基が配意した位置異性体であるが，GCの保 持時間はそれぞれ 9.3 分, 9.7 分及び 10.1 分と大き な差はなかった。 MS スペクトルは，AMT と 
NMT は $m / z 174,131,103$ 及び 77 に認め，区別はで きなかったが， 5MT は， $m / z$ 174,144,115 と両者と 異なり区別できた．HPLCでの保持時間及び TLC の Rf 值でも AMT と NMT は接近しており, $5 \mathrm{MT}$ のタが区別できた．IR スペクトルを比較した結果, AMT では $1580 \mathrm{~cm}^{-1}, 1100$ 付近に 2 本と $810 \mathrm{~cm}^{-1}$ 付近に吸収を認めたが，NMT は認めないなど若干 の違いがみられ，5MT で認めた $1514 \mathrm{~cm}^{-1}$ の吸収 を AMT では認めないなど違いを認めた。

ピペラジン系の $2 \mathrm{CPP}, 3 \mathrm{CPP}$ 及び $4 \mathrm{CPP}$ は, $\mathrm{GC}$ の保持時間は $3 C P P$ が 9.1 分で, 4 CPP が 9.2 分と 接近しており，2CPP は 7.8 分で分離できた。 MS スペクトルはいずれも同一で区別することができな かった。 IR スペクトルは 2CPP が $1480 \mathrm{~cm}^{-1}$ 付近 に，3CPP が $1450-1400 \mathrm{~cm}^{-1}$ に 2 本，4CPP が $820 \mathrm{~cm}^{-1}$ 付近に強い吸収があることからそれぞれ 少しずつ違いを認めた。 HPLCでは 3CPP が 11.5 分, 4 CPP が 11.4 分と接近しており, 2 CPP は 10.5 分と分離できた. TLC は，いずれも接近して いた。 2MPP と 4MPP では, GC と HPLC の保持 時間で分離できたが，TLCでは接近していた，MS スペクトルでは区別できなかったが，IR スペクト ルでは区別することができた.

フェネチルアミン系の TMA-2 と TMA-6 は, GC の保持時間は 9.1 分と 9.4 分で接近しており, MS スペクトルは TMA-6 で分子イオンがみられず， $m$ /z182,151,136,121 だったのに対し，TMA-2 は分子 イオンの $m / z 225$ に加え，182,167,151 と TMA-6 と違いがあった．IR スペクトルでも区別すること ができた。また，HPLCでは保持時間が 8.2 分と 12.0 分と分離でき，TLCでも区別できた。

3. 試買した 4-Acetoxy- $N, N$-di-iso-propyl-tryptamine (4AcO-DIPT) 及び 5-Methoxy- $N, N$-dimethyltryptamine (5MeO-DMT) の確認実際に，実態 調査をする中で，4AcO-DIPT 及び 5MeO-DMT を 検出した。この場合，それぞれ 4-acetoxy-di- $(n)$ propyl-tryptamine (4AcO-DPT) あるいは 5-methoxy-ethyl-tryptamine (5MeO-ET) と区別する必要が あると判断した。 そこで，GC-MS， HPLC，TLC， FT-IR 測定を行ったが，対象とすべき試薬を保有し ないことから最終判断はできなかった。そこで ${ }^{1} \mathrm{H}-$ NMR による測定を行った. Table 5 に得られた ${ }^{1} \mathrm{H}$ のデータを示したように，4AcO-DIPT と予想した
Table 5. ${ }^{1} \mathrm{H}$ NMR Data of Commercial Compounds (400 $\left.\mathrm{MHz}, \delta, \mathrm{D}_{2} \mathrm{O}\right)$

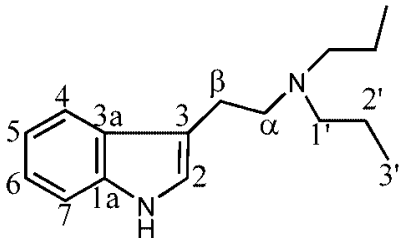

Tryptamine基本骨格

\begin{tabular}{lll}
\hline \hline Position & \multicolumn{1}{c}{ 4AcO-DIPT } & \multicolumn{1}{c}{$5 \mathrm{MeO}-\mathrm{DMT}$} \\
\hline 2 & $7.236(1 \mathrm{H}, \mathrm{s})$ & $7.132(1 \mathrm{H}, \mathrm{s})$ \\
4 & & $7.107(1 \mathrm{H}, \mathrm{d}, j=2.4)$ \\
5 & $6.784(1 \mathrm{H}, \mathrm{d}, j=7.8)$ & \\
6 & $7.153(1 \mathrm{H}, \mathrm{t}, j=7.9)$ & $6.830(\mathrm{dd}, j=8.8,2.4)$ \\
7 & $7.358(1 \mathrm{H}, \mathrm{d}, j=8.1)$ & $7.331(1 \mathrm{H}, \mathrm{d}, j=8.8)$ \\
$\alpha$ & $3.089(2 \mathrm{H}, \mathrm{t}, j=7.8)$ & $2.662(2 \mathrm{H}, \mathrm{t}, j=7.9)$ \\
$\beta$ & $3.342(2 \mathrm{H}, \mathrm{t}, j=7.8)$ & $2.858(2 \mathrm{H}, \mathrm{t}, j=7.9)$ \\
$N-1^{\prime}$ & $3.673(2 \mathrm{H}, \mathrm{m})$ & $2.259(6 \mathrm{H}, \mathrm{s})$ \\
$N-2^{\prime}$ & $1.237(12 \mathrm{H}, \mathrm{d}, j=6.8)$ & \\
$4-$ Acetoxy & $2.368(3 \mathrm{H}, \mathrm{s})$ & \\
5-OMe & & $3.795(3 \mathrm{H}, \mathrm{s})$ \\
\hline
\end{tabular}

$\delta$ values in ppm and coupling constants (in parentheses) in $\mathrm{Hz}$.

検体の $3.673 \mathrm{ppm}$ は窒素に結合する isopropyl 基の 炭素に結合する $\mathrm{H}$ に， $3.342 \mathrm{ppm}$ は $\beta$ 位の $\mathrm{H}$ に, $3.089 \mathrm{ppm}$ は $\alpha$ 位の $\mathrm{H}$ に，2.368 ppm は acetoxyl 基の $\mathrm{C}$ に結合する $\mathrm{H}$ に， $1.237 \mathrm{ppm}$ は，isopropyl 基における methyl 基の $\mathrm{H}$ に由来すると解析され た。また，5MeO-DMT と予想される検体では， $3.795 \mathrm{ppm}$ は methoxyl 基の $\mathrm{H}$ に, $2.858 \mathrm{ppm}$ は $\beta$ 位の $\mathrm{H}$ に, $2.662 \mathrm{ppm}$ は $\alpha$ 位の $\mathrm{H}$ に, $2.259 \mathrm{ppm}$ は $\mathrm{N}$ に結合する methyl 基の $\mathrm{H}$ に由来すると解析 されたことから，検体は，4AcO-DIPT 及び $5 \mathrm{MeO}-$ DMT と決定した.

考察

最近出回っているケミカルドラッグ類は，トリプ タミン系，ピペラジン系，フェネチルアミン系，亜 硝酸イソブチル類のニトライト系などに分類され る5)が，これらの種類の数の正確な把握はなされて いない．これらの内，麻薬及び向精神薬取締法で規 制されているのは一部に過ぎず，多くのケミカルド ラッグは，薬理作用など不明な点が多いことから， 強い作用が予想されるにも係わらず放置されてい る。トリプタミン系では，麻薬に指定された 5MeO-DIPT あるいは 2C-T-7 に対し，連鎖構造異 
性体の 5MeO-DPT あるいは 2C-T-4 及び 2,6dimethoxy-4-iso-propylthio-phenethylamine ( $\psi$-2CT-4) は指定外であり，同様に麻薬の AMT に対し, 位置構造異性体の NMT 及び 5MT は指定されてい ない。これらは確実に構造が特定されなければ取り 締まることはできない，また，麻薬及び向精神薬取 締法で規制されていないものでも，トリプタミン系 では，この他に $N$-methyl-N-iso-propyl-tryptamine (MIPT), 4OH-MIPT, 4AcO-MIPT 及び 5-methoxy$N$-methyl- $N$-iso-propyl-tryptamine (5MeO-MIPT) が

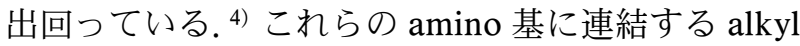
基の $\mathrm{C}$ の数が同じ連鎖構造異性体として, $N, N$-diethyl-tryptamine (DET), 4HO-DET 及び 4AcO-DET は販売されているが, methyl 基と $n$-propyl 基のも の（MPT, 4HO-MPT, 4AcO-MPT と省略される化 合物）に関しては販売の実態はつかめていない。ピ ペラジン系の $2 \mathrm{CPP}, 3 \mathrm{CPP}$ 及び 4CPP や 2MPP, 1(3-methoxyphenyl) -piperazine (3MPP) 及び 4MPP
等の位置構造異性体，フエネチルアミン系の TMA-2 及び TMA-4 の位置構造異性体等多くの構 造相似体が流通しているとみられることからこれら の区別が必要不可欠となる.

今回示したように，試薬として販売されているケ ミカルドラッグについて構造並びに純度を確認した もの及び試薬で入手できたものについて，GC-MS， HPLC-PDA-FL のデータに加え TLC 等多くの手段 で比較した。試料はいずれも $95 \%$ 以上の純度を有 することから，抽出方法等の検討は行わなかった. いずれもメタノールあるいはエタノールに溶解して 測定した. その結果 5MeO-DIPT と 5MeO-DPT は, MS スペクトルでは違いがなかったが，HPLCある いは TLCで区別ができた，AMT，NMT 及び 5MT の内，5MT は GC-MS 及び HPLC により区別でき るが, AMT と NMT は GC-MS と HPLC では区別 できず，TLCのみが区別可能だった．また，Table 6 に示したように，さらに7MTなどの位置異性体

Table 6. Chemical Drugs to Make Difference from Each Others

\begin{tabular}{|c|c|}
\hline Type & Examples of chemical drug \\
\hline \multirow{12}{*}{ Tryptamine } & $5 \mathrm{MeO}-\mathrm{DIPT}$ and $5 \mathrm{MeO}-\mathrm{DPT}$ \\
\hline & DIPT and DPT \\
\hline & $\operatorname{AMT}(\alpha-\mathrm{MT}), \mathrm{NMT}, 2 \mathrm{MT}, 5 \mathrm{MT}$ and $7 \mathrm{MT}$ \\
\hline & MIPT, MPT and DET \\
\hline & 4HO-MIPT, 4HO-MPT and 4HO-DET \\
\hline & 4AcO-MIPT, 4AcO-MPT and 4AcO-DET \\
\hline & 5MeO-MIPT, 5MeO-MPT, 5MeO-DET, 4MeO-MIPT, 4MeO-MPT and 4MeO-DET \\
\hline & 4HO-DIPT and 4HO-DPT \\
\hline & 4HO-DMT and 5HO-DMT \\
\hline & 2,4-DMA, DESOXY, 2,5-DMA and 3,4-DMA \\
\hline & $\alpha, N$-DMT $, 2, \alpha$-DMT, DMT and NET \\
\hline & $\alpha, N, \mathrm{O}-\mathrm{TMS}, 5 \mathrm{MeO}-\mathrm{DMT}, 6 \mathrm{MeO}-\mathrm{DMT}$ and $7 \mathrm{MeO}-\mathrm{DMT}$ \\
\hline \multirow{3}{*}{ Piperazine } & 2MPP, 4MPP and 3-methoxyphenyl piperazine \\
\hline & 3CPP and 2- and 4-chlorophenyl piperazine \\
\hline & TFMPP and 2- and 4-trifluoromethylphenyl piperazine \\
\hline \multirow{5}{*}{ Phenethylamine } & TMA, TMA-2, TMA-3, TMA-4, TMA-5 and TMA-6 \\
\hline & $2 \mathrm{C}-\mathrm{T}-8$ and $2 \mathrm{C}-\mathrm{T}-9$ \\
\hline & $2 \mathrm{C}-\mathrm{T}-7,2 \mathrm{C}-\mathrm{T}-4, \psi-2 \mathrm{C}-\mathrm{T}-4$ and $2 \mathrm{C}-\mathrm{T}-15$ \\
\hline & 3-TME, 4-TME and 5-TME \\
\hline & $N, N$-dimethyl-MDA and $N$-ethyl-MDA \\
\hline
\end{tabular}


と区別する必要がある。4HO-MIPT と $4 \mathrm{HO}-\mathrm{DET}$ について比較した結果，TLC, HPLC, MS では区 別できず，IR でも 4HO-MIPT と 4HO-DET は主 要な吸収波数は一致し，区別は難しかった。末端の amino 基に結合する alkyl 基が $n$-propyl となる 4hydroxy- $N$-methyl- $N$ - $(n)$-propyl-tryptamine (4HOMPT）に関しては試薬の入手ができず測定できな かった。このように想定される対照となる試薬等は 保有しているが，関連する構造異性体成分を保有し ない場合では，NMR スペクトルデータが要求され ると考える。ピペラジン系の $2 \mathrm{CPP}, 3 \mathrm{CPP}$ 及び 4CPPでは，2CPPのみが区別可能で，3CPP と 4CPP は対照品によるコクロマトで区別することが 求められると考える。 しかし，対照品を保有しない 場合には，HPLC 等分離条件（理論段や分離度等） の特定がなされなければ HPLC 等の分析を加えて も判断できない，IR スペクトルでの違いもみられ たが，いずれの対照品も必要になると考える．ピペ ラジン系の $2 \mathrm{MPP} と 4 \mathrm{MPP}$ 及びフェネチルアミン 系の TMA-2 と TMA-6 では，HPLC による区別が できたが，3MPP あるいは 2,3,4-trimethoxy-amphetamine (TMA-3) や 2,3,5-trimethoxy-amphetamine（TMA-5）などの構造異性体に関しては試薬 の入手ができず測定できなかった，麻薬に指定され た 2C-T-7 に対し，その連鎖構造異性体の 2C-T-4 はクロマトグラム手法を組み合わせることにより区 別が可能だったが，連鎖及び位置異性体の $\psi$ 2C-T-4 との区別は， $\psi$-2C-T-4 を確保できなかった ことからデータが得られなかった。

以上のように，対象となる試薬等構造が確認でき たものを指標として判断する場合は各クロマトグラ フによる組み合わせで判断できるが，構造異性体の 対照品をすべて保有しているか確認する必要があ る. すなわち，例え 1 つの対照品と同じデータでも， MIPT と MPT と DET のように異なるアルキル基 を有するものとの区別ができているか確認が必要と なる. Shulgin and Shulgin ${ }^{6,7)}$ を参考に，ケミカル ドラッグ成分を分析するに当たり検討が必要となる 成分を Table 6 に示した。しかし，これはほんの 1
例に過ぎずさらに多くの成分が見受けられる。した がって，分析時に対照となるケミカルドラッグ成分 を保有しない場合には，最終手段として NMR によ る確認が求められる。しかし，試薬として販売され ている成分は少なく，違法ドラッグとして購入する か，あるいは合成しなければすべての対照品を保有 することはできない，そこで，判定が難しい成分に ついては NMR による構造解析が欠くべからざるも のとなる.

さらに，光学異性体の存在も生体影響を検討する 場合には区別が必要となることも言及される，少な くとも，麻薬に指定されている成分及びそのすべて の構造異性体については国が標準品を保有し，必要 に応じて配布するか, 各種スペクトルデータを示す 必要があると考える。現状は，行政の取締と販売者 側のいたちごっこのように次々と新たなケミカルド ラッグが製造販売されている。このような現状か ら，販売実態の調查は欠くことができないが，その 分析に際しては，構造異性体に関する注意及び確認 が不可欠と考える.

\section{REFERENCES}

1) Kuroki Y., Jpn. J. Toxicol., 17, 241-243 (2004).

2) Yamamoto J., Jpn. J. Toxicol., 17, 245-250 (2004) .

3) Kojima T., Uemura H., Doi K., Setsuda S., Kishi M., Sekita S., Satake M., Jpn. J. Toxicol., 13, 85-86 (2000).

4) Kojima T., Miyazawa M., Ishikawa T., Takayanagi E., Asaya H., Doi K., Jpn. J. Toxicol., 17, 71-72 (2004).

5) Tabe M., Itoh E., Kawano Y., Jpn. J. Toxicol., 17, 251-258 (2004).

6) Shulgin A., Shulgin A., "PiHKAL A Chemical Love Story," ed. by Dan J., Transform Press, California, 2000, pp. 451-923.

7) Shulgin A., Shulgin A., "TiHKAL The Contituation," ed. by Dan J., Transform Press, California, 1997, pp. 387-589. 